Hydrology and Earth System Sciences, 5(3), 477-486 (2001) C C EGS

\title{
Climate change as a confounding factor in reversibility of acidification: RAIN and CLIMEX projects
}

\author{
R.F. Wright ${ }^{1}$ and A. Jenkins ${ }^{2}$ \\ ${ }^{1}$ Norwegian Institute for Water Research, P.O. Box 173 Kjelsås, N-0411 Oslo, Norway \\ ${ }^{2}$ Centre for Ecology and Hydrology, Wallingford, OX10 8BB, UK
}

Email for corresponding author: richard.wright@niva.no

\begin{abstract}
The RAIN and CLIMEX experiments at Risdalsheia, southernmost Norway, together cover 17 years (1984-2000) of whole-catchment manipulation of acid deposition and climate. A $1200 \mathrm{~m}^{2}$ roof placed over the forest canopy at KIM catchment excluded about $80 \%$ of ambient acid deposition; clean rain was sprinkled under the roof. A climate change treatment $\left(3.7^{\circ} \mathrm{C}\right.$ increase in air temperature and increase in air carbon dioxide concentrations to $560 \mathrm{ppmv}$ ) was superimposed on the clean rain treatment for four years (1995-1998). Sea-salt inputs and temperature are climate-related factors that influence water chemistry and can confound long-term trends caused by changes in deposition of sulphur and nitrogen. The RAIN and CLIMEX experiments at Risdalsheia provided direct experimental data that allow quantitative assessment of these factors. Run-off chemistry responded rapidly to the decreased acid deposition. Sulphate concentrations decreased by $50 \%$ within three years; nitrate and ammonium concentrations decreased to new steady-state levels within the first year. Acid neutralising capacity increased and hydrogen ion and inorganic aluminium decreased. Similar recovery from acidification was also observed at the reference catchment, ROLF, in response to the general 50\% reduction in sulphate deposition over southern Norway in the late 1980s and 1990s. Variations in sea-salt deposition caused large variations in run-off chemistry at the reference catchment ROLF and the year-to-year noise in acid neutralising capacity was as large as the overall trend over the period. These variations were absent at KIM catchment because the seasalt inputs were held constant over the entire 17 years of the clean rain treatment. The climate change experiment at KIM catchment resulted in increased leaching of inorganic nitrogen, probably due to increased mineralisation and nitrification rates in the soils.
\end{abstract}

Keywords: acid deposition, global change, water, soil, catchment, experiment, Norway.

\section{Introduction}

Reduction in emissions of acidifying compounds in Europe and eastern North America during the past 20 years has led to decreased deposition of sulphur (S) and nitrogen $(\mathrm{N})$. In response, surface waters in many areas are recovering from acidification (Stoddard et al., 1999; Skjelkvåle et al., 2001b; Evans et al., 2001). Trends in acidification parameters such as $\mathrm{pH}$ and acid neutralising capacity (ANC), however, have seldom been smooth or monotonic, as the chemistry of acidified waters is also affected by variations in climate, deposition of sea-salts and other factors independent of acid deposition.

The Norwegian RAIN project (Reversing Acidification In Norway) (Wright et al., 1988; Wright et al., 1993) experimentally demonstrated that surface water acidification was reversible. The site, Risdalsheia, is located on the south coast in the zone of maximum acid deposition for Norway.
The RAIN project used a $1200 \mathrm{~m}^{2}$ roof structure to exclude ambient acid deposition from an entire forested headwater catchment (Fig. 1). The experiment began in June 1984 and lasted 17 years (ending in May 2000).

In 1994, transparent walls were added to the roofed structure and a climate change manipulation (CLIMEX project) was superimposed on the clean rain treatment (van Breemen et al., 1998). The climate change manipulation was maintained for four years (June 1994 - June 1998). When the climate change treatment was stopped, the experiment continued with clean rain only for one year (June 1998 - June 1999), the roof and side panels were removed, and the site monitored for a final year with no treatment (ambient acid deposition and no climate change) (June 1999 - May 2000). The final sample was collected on 31 May 2000 and the facility has now been dismantled.

Results from the CLIMEX project have been assessed 


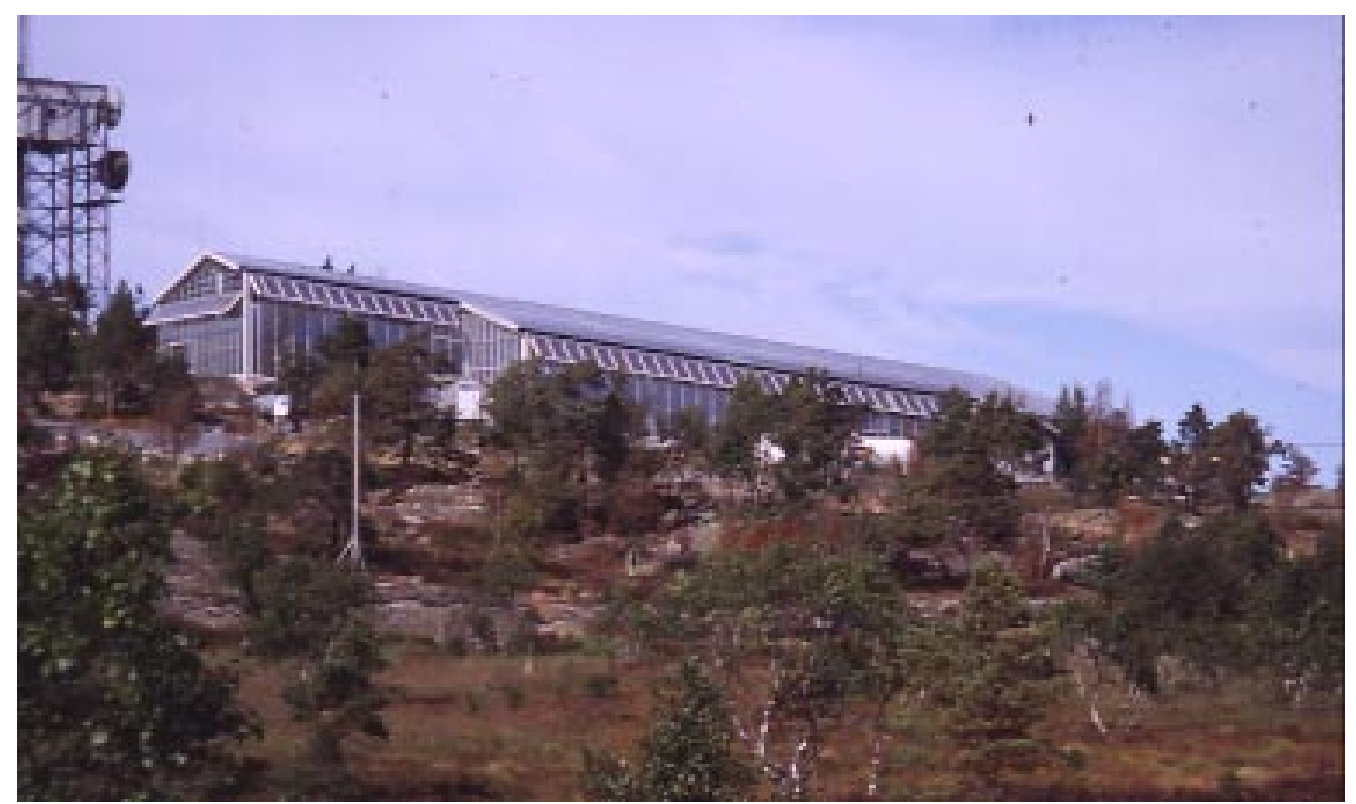

Fig. 1. The greenhouse enclosing KIM catchment, Risdalsheia, southern Norway

primarily in terms of the ecosystem response to combined change in temperature and carbon dioxide $\left(\mathrm{CO}_{2}\right)$ with the experiment considered in the context of future global change (Wright, 1998; van Breemen et al., 1998). The CLIMEX treatment can also be used to understand the potentially confounding effects of climate change on the reversibility of acidification. Climatic effects might explain the observed noise in long-term trends in surface water chemistry across Europe and it is also possible that climate change will have an impact on the surface water chemistry response to future reductions in acid deposition.

This paper presents the precipitation and run-off data for the entire 17 year record from the roof experiment at Risdalsheia, and evaluates the confounding effect of climate variations in reversibility of water acidification. Previous results from these experiments have been presented after one year of treatment (Wright et al., 1986), two years of treatment (Wright, 1987), four years of treatment (Wright et al., 1988), eight years of treatment (Wright et al., 1993), and after three years of CLIMEX treatment (Wright, 1998).

\section{Site description and methods}

\section{SITE DESCRIPTION}

Risdalsheia is $300 \mathrm{~m}$ above sea level about $20 \mathrm{~km}$ from the south coast near Grimstad, Norway (58 $\left.23^{\prime} \mathrm{N}, 8^{\circ} 19^{\prime} \mathrm{E}\right)$. The site is typical of large areas of upland southern Norway, with sparse and patchy forests of pine (Pinus sylvestris L.) and birch (Betula pubescens L.) and dominant ground vegetation of heather (Calluna vulgaris L.) and blueberry
(Vaccinium mrytillus L.). Soils are organic-rich, poorlydeveloped podsols on patches of granitic glacial till. Average soil depth is about $10 \mathrm{~cm}$ with pockets up to $70 \mathrm{~cm}$ deep (Verburg et al., 1999a). About 30-50\% of the surface is bare granite bedrock.

Risdalsheia has a maritime climate with mean annual precipitation of about $1400 \mathrm{~mm}$, run-off of about $1200 \mathrm{~mm}$ and mean annual temperature of $5.4^{\circ} \mathrm{C}$. The site receives high levels of acid deposition with mean annual deposition (wet plus dry) in 1984-1992 of $113 \mathrm{meq} \mathrm{m}^{-2} \mathrm{yr}^{-1}$ sulphate $\left(\mathrm{SO}_{4}\right), 132 \mathrm{meq} \mathrm{m}^{-2} \mathrm{yr}^{-1}$ nitrogen $(\mathrm{N})$ (59 as ammonium $\left(\mathrm{NH}_{4}\right)$ and 73 as nitrate $\left.\left(\mathrm{NO}_{3}\right)\right)$ and 106 meq $\mathrm{m}^{-2} \mathrm{yr}^{-1}$ hydrogen $(\mathrm{H})$ (Wright et al., 1993).

\section{TREATMENTS}

The experiments at Risdalsheia utilised five catchments (Table 1). KIM catchment was covered by a roof, received clean rain and then was completely enclosed and received increased $\mathrm{CO}_{2}$ and warming; EGIL catchment was covered by a roof but received recycled ambient acid deposition (roof control). Results from the RAIN project in which KIM was compared with EGIL catchment showed that there was no significant roof effect (Wright et al., 1993). EGIL catchment was then manipulated by soil warming with electric heating cables. ROLF, MET, and CEC catchments served as untreated references. They have similar run-off chemistry. The climate treatments at both KIM and EGIL catchments were confined to the lower $80 \%$ of the catchment; the upper $20 \%$ was partitioned to serve as untreated control for plant and soil studies. Details and results from the soil warming 
Table 1. Overview of the five catchments at Risdalsheia included in the RAIN and CLIMEX projects. The first three were run by the RAIN project for 11 years (June 1983 - May 1994). Clean rain treatment began in June 1984. CLIMEX treatment began in April 1994. KIM and EGIL were divided in April 1994 to an upper control section (KIM-c, EGIL-c, no climate change) and lower treatment section (KIM-t, EGIL-t, climate change). CLIMEX treatment stopped in July 1998. The roof panels at KIM were removed in August 1999. The last sample was collected in May 2000.

\begin{tabular}{lllllll}
\hline Catchment & area $m^{2}$ & enclosure & rain quality & climate treatment & monitor start & monitor end \\
\hline KIM & 860 & roof & clean & $\mathrm{CO}_{2}+$ air warming & Mar 1984 & May 2000 \\
EGIL & 400 & roof & ambient & soil warming & Mar 1984 & Nov 1998 \\
ROLF & 220 & open & ambient & none & Oct 1984 & May 2000 \\
MET & 650 & open & ambient & none & May 1993 & Jul 1999 \\
CEC & 380 & open & ambient & none & May 1993 & May 1997 \\
\hline
\end{tabular}

experiment at EGIL are given by Lükewille and Wright (1997) and Verburg et al., (1999a). Dise and Jenkins (1995) give details on the soils, vegetation and treatments at all catchments. Here, only the results from KIM (clean rain; temperature and $\mathrm{CO}_{2}$ treatment) and the reference catchment with the longest record, ROLF (reference), are discussed.
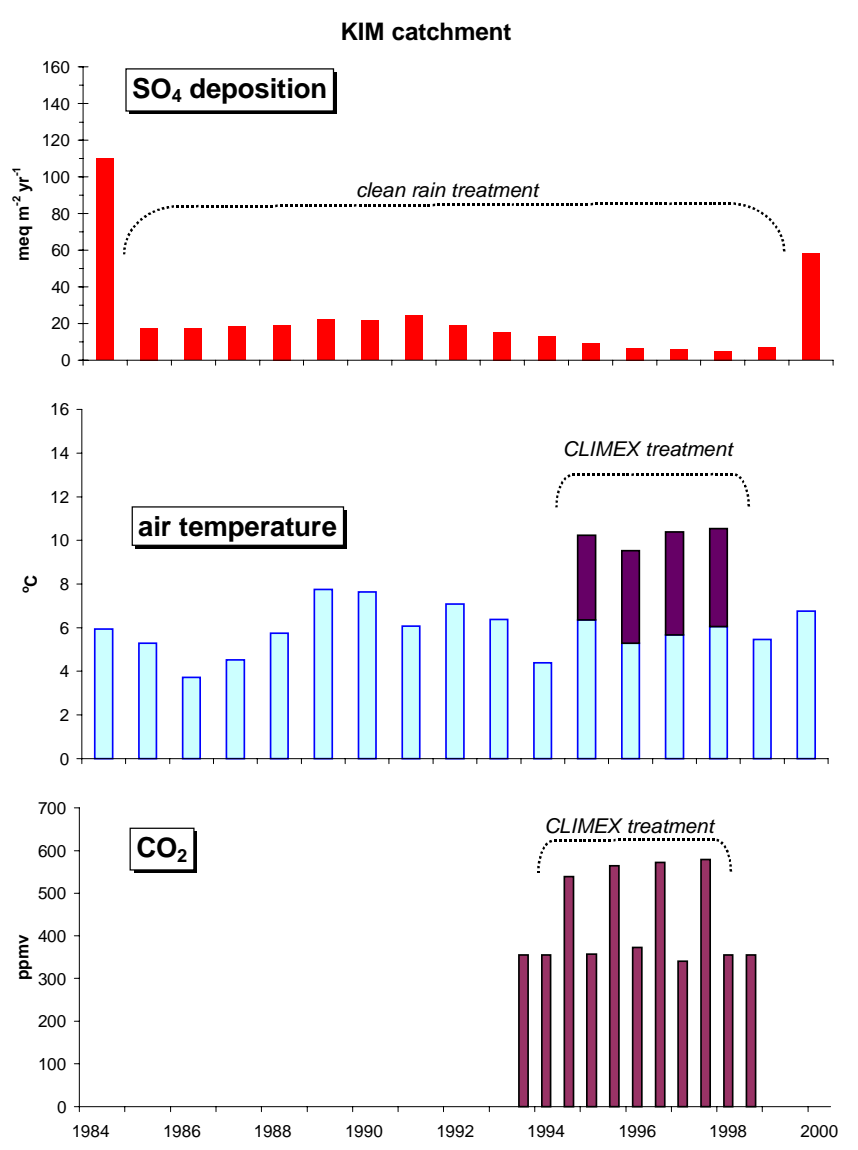

Fig. 2. The clean rain and climate treatments at KIM catchment. Annual values of $\mathrm{SO}_{4}$ deposition, temperature and $\mathrm{CO}_{2}$.
The climate change treatment at KIM catchment $\left(\mathrm{CO}_{2}\right.$ plus warming) was nested within a long-term manipulation of acid deposition input at the same catchment (Fig. 2). In winter 1984, a transparent roof with open walls was constructed over KIM catchment to intercept the ambient acid precipitation. Ion-exchanged "clean" rain with natural levels of sea-salts was sprinkled beneath the roof. The treatment protocol entailed addition of dilute sea-water to the ion-exchanged clean rain at a fixed concentration. This was the RAIN project. In May 1994 the roof structure was fitted with airtight transparent walls, a dosing system for $\mathrm{CO}_{2}$, roof-mounted circulation fans, movable panels on the walls to vent excess heat and a heating system. A computercontrolled regulation system fixed $\mathrm{CO}_{2}$ levels at $560 \mathrm{ppmv}$ during the growing season (April through October) and increased air temperature by $3^{\circ} \mathrm{C}$ during the summer and $5^{\circ} \mathrm{C}$ during the winter, with intermediate temperatures during the intervening months (Dise and Jenkins, 1995). The climate change treatment was stopped in July 1998. The system was then run for one additional year with the clean rain treatment, but ambient climate. This was the CLIMEX project. Finally the roof panels were removed in August 1999 and run-off monitored for a final year, with ambient climate and ambient acid deposition.

\section{SAMPLING AND ANALYTICAL METHODS}

Ambient bulk precipitation was collected weekly. Precipitation under the roof at KIM catchment was metered. Run-off from the catchments was collected at fibreglass dams at the bottom of each catchment. Discharge volume was metered, and spot samples for chemical analysis collected weekly. Precipitation samples were analysed for major ions and run-off for major ions, aluminium ( $\mathrm{Al}$ ) species and total $\mathrm{N}$, phosphorus $(\mathrm{P})$ and carbon $(\mathrm{C})$ at the Norwegian Institute for Water Research (Wright, 1998). 
Dry deposition of marine aerosols was calculated by the difference between the annual chloride $(\mathrm{Cl})$ flux in run-off and the annual $\mathrm{Cl}$ flux in bulk precipitation. The chemical composition of marine aerosols was assumed to be the same

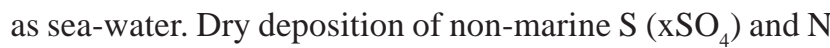
was estimated from average concentrations of $\mathrm{S}$ and $\mathrm{N}$ compounds in gases and in particles measured daily at the nearby station at Birkenes (Tørseth et al., 1999) and assuming deposition velocities of $0.7 \mathrm{~cm} \mathrm{~s}^{-1}$ for $\mathrm{SO}_{2}$ gas, $0.4 \mathrm{~cm} \mathrm{~s}^{-1}$ for $\mathrm{SO}_{4}$ particulates, $0.25 \mathrm{~cm} \mathrm{~s}^{-1}$ for $\mathrm{NO}_{2}$ gas, and $2.0 \mathrm{~cm} \mathrm{~s}^{-1}$ for $\mathrm{HNO}_{3}+\mathrm{NO}_{3}$ gas, respectively. Dry deposition of $\mathrm{NH}_{4}$ was assumed to be proportional to that of $\mathrm{SO}_{4}$ particulates with a molar ratio of $1.5\left(\mathrm{SO}_{4} / \mathrm{NH}_{4}\right)$. The remaining positive charge in dry deposition was assumed to be $\mathrm{H}$.

Sum of base cations (SBC) was defined as the equivalent sum of calcium $(\mathrm{Ca})+$ magnesium $(\mathrm{Mg})+\operatorname{sodium}(\mathrm{Na})+$ potassium $(\mathrm{K})+\mathrm{NH}_{4}$ concentrations, sum of strong acid anions (SAA) as the equivalent sum of $\mathrm{SO}_{4}+\mathrm{Cl}+\mathrm{NO}_{3}$ concentrations, and acid neutralising capacity (ANC) as SBC-SAA.

\section{Results}

\section{LONG-TERM TRENDS IN RUN-OFF CHEMISTRY}

The clean rain treatment at KIM catchment was continuous from May 1984 to July 1999. Year is defined as May the previous year to May the current year. During that period, $\mathrm{SO}_{4}$ inputs were reduced from ambient levels (in 1984) of about $110 \mathrm{meq} \mathrm{m}^{-2} \mathrm{yr}^{-1}$ to about $20 \mathrm{meq} \mathrm{m}^{-2} \mathrm{yr}^{-1}$ (Fig. 2). This $20 \mathrm{meq} \mathrm{m}^{-2} \mathrm{yr}^{-1}$ included wet and dry deposition of sea-salts (about 10 to $15 \mathrm{meq} \mathrm{m}^{-2} \mathrm{yr}^{-1}$ ) and dry deposition of $\mathrm{S}$ gases and particulates (about 6 to 8 meq $\mathrm{m}^{-2} \mathrm{yr}^{-1}$ ). Inputs of $\mathrm{SO}_{4}$ at KIM catchment decreased further in May 1994 when the air-tight walls were installed for the climate change treatment. These walls probably excluded most dry deposition.

Concentrations of $\mathrm{SO}_{4}$ in run-off at KIM catchment decreased rapidly and exponentially during the first few years of treatment to a new level of about $30 \mu \mathrm{eq}^{\mathrm{I}^{-1}}$ by 1991 (Fig. 3). At the reference catchment ROLF, $\mathrm{SO}_{4}$ concentrations remained high and very variable at 70-110 $\mu$ eq $\mathrm{l}^{-1}$ during this period.

Concentrations of $\mathrm{SO}_{4}$ in run-off at KIM catchment decreased further to $c .20 \mu \mathrm{eq}^{-1}$ in 1995 in response to the exclusion of dry deposition (Fig. 3). No observable difference was detected between the $\mathrm{SO}_{4}$ run-off from the climate treatment and control areas of KIM (Wright, 1998). Concurrently, ambient deposition of S at ROLF catchment began a major decline beginning in about 1990. This decline
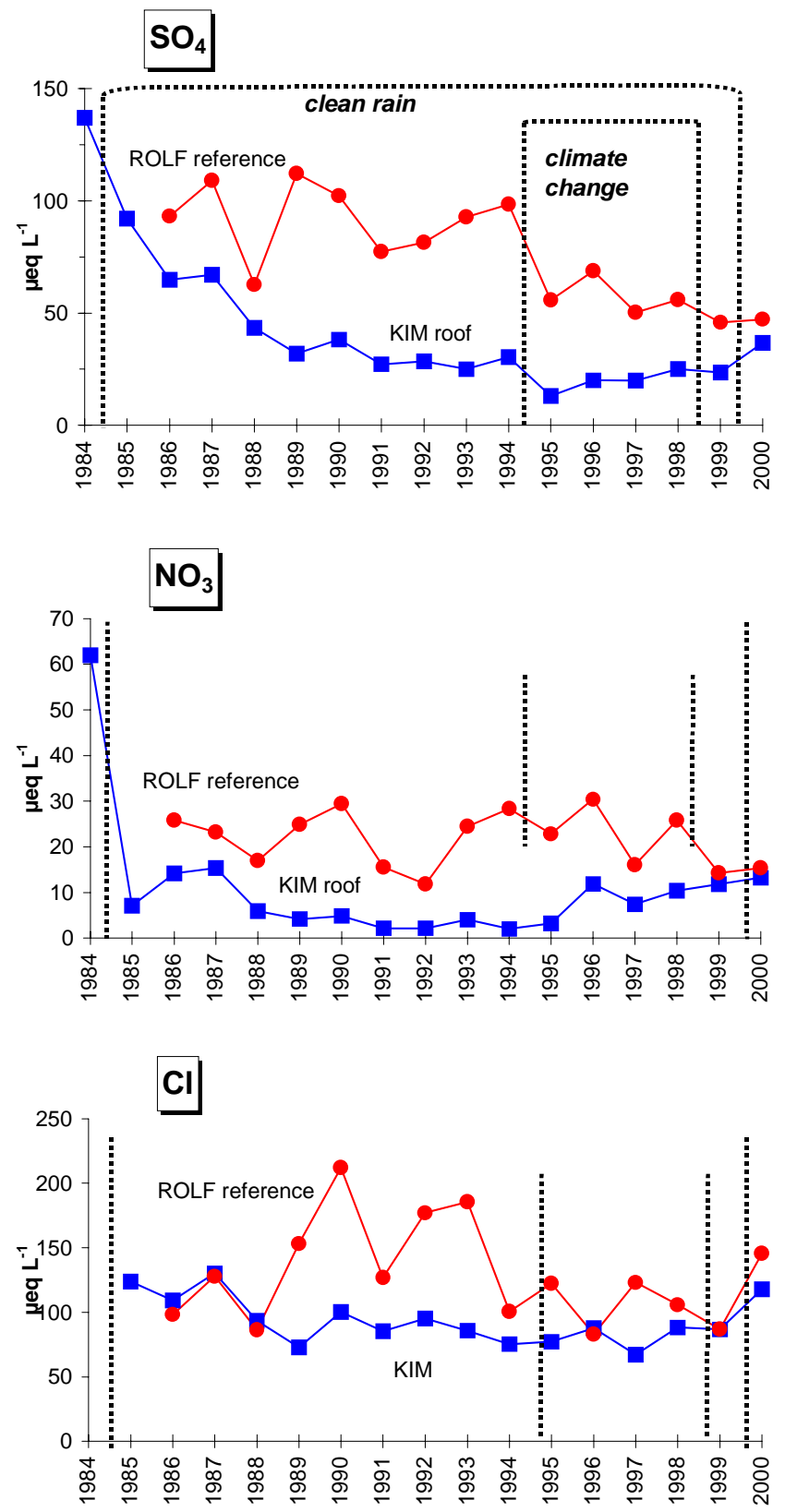

Fig. 3. Volume-weighted average concentrations of the strong acid anions $\mathrm{SO}_{4}, \mathrm{NO}_{3}$ and $\mathrm{Cl}$ in run-off at KIM (treatment squares) and ROLF (reference, circles) catchments

was general over all of southern Norway and during the 1990s deposition of $\mathrm{SO}_{4}$ decreased by about 50\% (Tørseth et al., 1999).

Input-output budgets for $\mathrm{SO}_{4}$ show that KIM catchment released an average of $c .140$ meq $\mathrm{m}^{-2} \mathrm{yr}^{-1}$ of stored $\mathrm{SO}_{4}$ from the soil pool during the period 1985-1991 as the catchment adjusted to the new low level of $\mathrm{SO}_{4}$ inputs (Fig. 4). This "bleeding" of stored $\mathrm{SO}_{4}$ continued, albeit at a lower rate, until the clean rain treatment stopped in 2000 . 
KIM catchment (treatment)
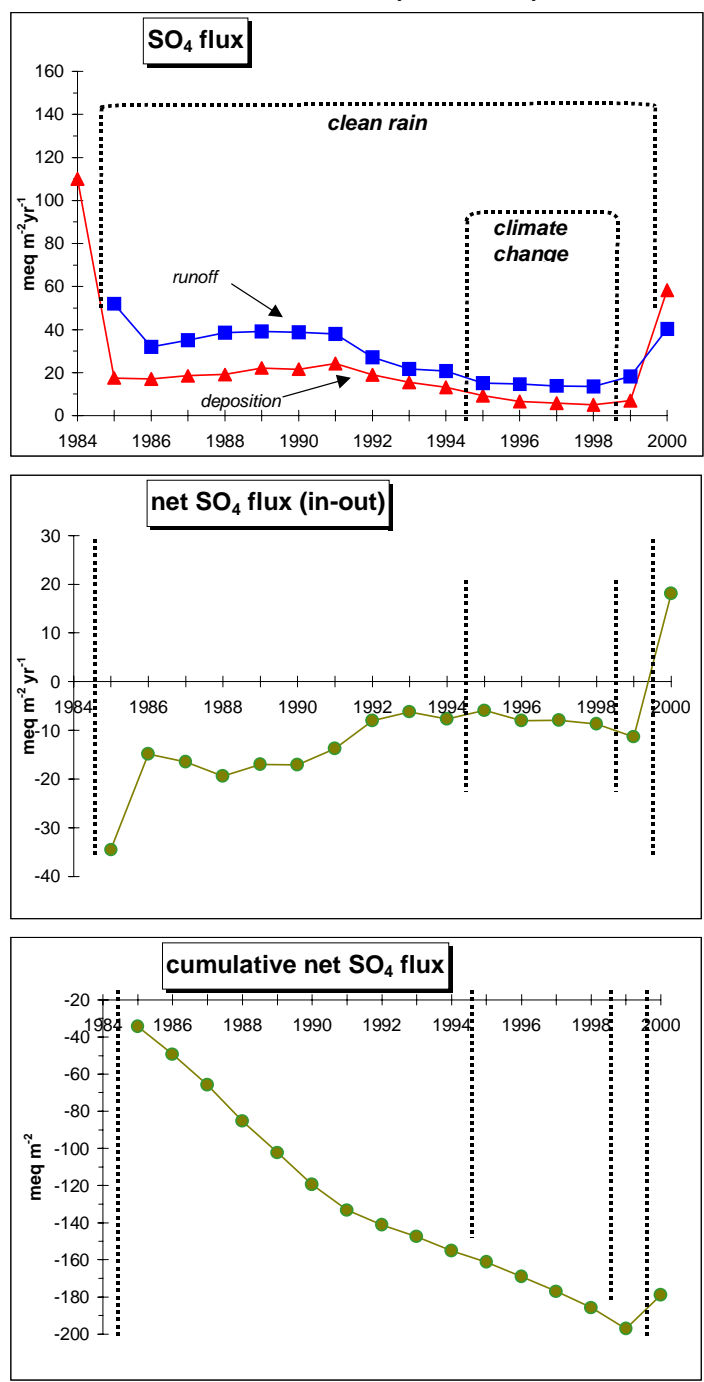

ROLF catchment (reference)
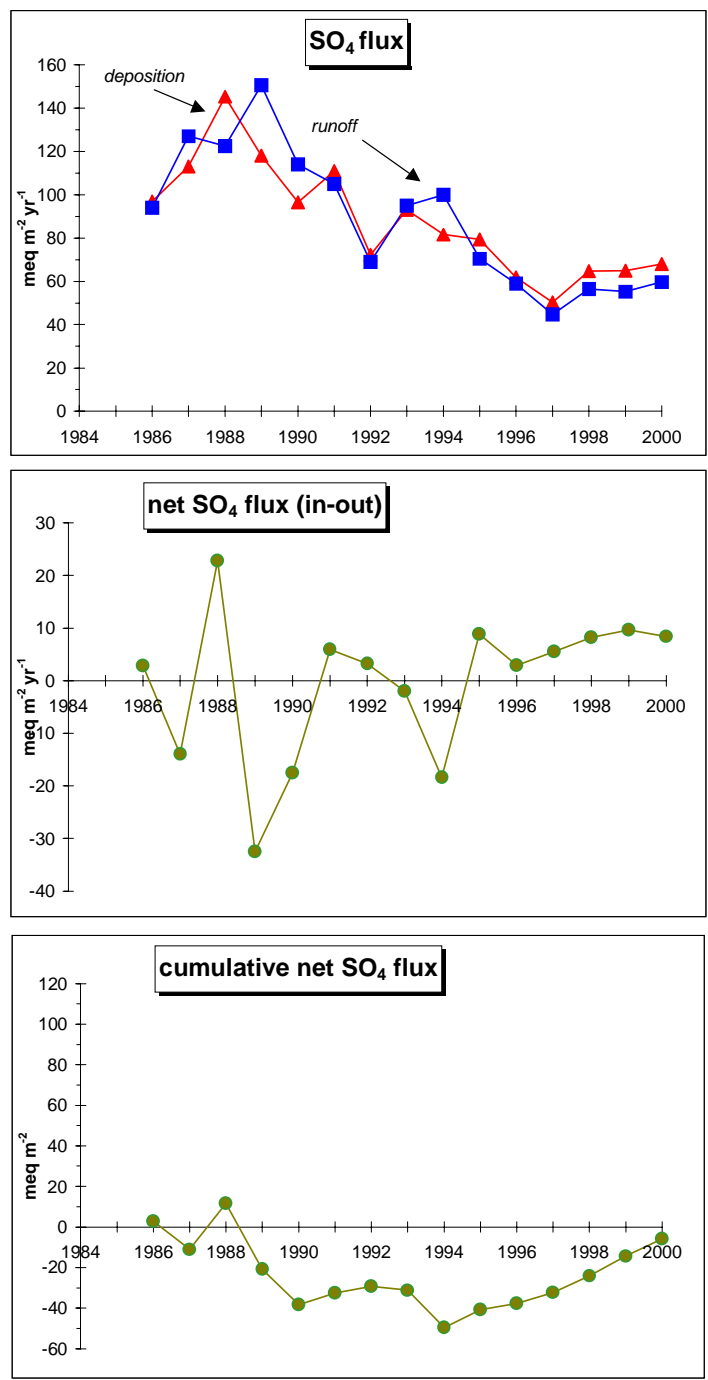

Fig. 4. Annual flux of $\mathrm{SO}_{4}$ in deposition (in; triangles) and run-off (out; squares), net flux (in-out) and cumulative net flux at KIM and ROLF catchments. Dotted lines denote start and end of the clean rain and climate change treatments at KIM catchment.

Net release of $\mathrm{SO}_{4}$ also occurred at ROLF catchment in response to the decrease in ambient $\mathrm{SO}_{4}$ deposition during the 1990s (Fig. 4). Cumulative net loss was $60 \mathrm{meq}^{-2}$ $\mathrm{yr}^{-1}$ by 1994 , about one-half the amount lost at KIM catchment. The reduction in $\mathrm{SO}_{4}$ deposition at $\mathrm{ROLF}$ catchment was also about one-half that at KIM catchment.

The clean-rain treatment also eliminated all wet deposition inputs of $\mathrm{NO}_{3}$ and $\mathrm{NH}_{4}$, although dry deposition of $\mathrm{N}$ compounds continued. Consequently, deposition of $\mathrm{NO}_{3}$ decreased from 73 (ambient 1984-1992) to $12 \mathrm{meq} \mathrm{m}^{-2} \mathrm{yr}^{-1}$, and $\mathrm{NH}_{4}$ decreased from 57 to $6 \mathrm{meq} \mathrm{m}^{-2} \mathrm{yr}^{-1}$. Nitrate concentrations in run-off at KIM catchment responded promptly to the decreased deposition of N (Fig. 3). Almost immediately, in 1985, the first year of treatment, concentrations of $\mathrm{NO}_{3}$ had fallen to below $10 \mu \mathrm{eq} \mathrm{l}^{-1}$ and remained low for most of the subsequent years. The somewhat higher levels in 1986 and 1987 were due to difficulties with the watering system; less water was added beneath the roof than fell as ambient precipitation outside. These years were, therefore, exceptionally dry under the roof at KIM catchment, and run-off had higher concentrations, but not an unusually high flux, of N (Fig. $6)$.

At ROLF catchment $\mathrm{NO}_{3}$ concentrations in run-off varied between 10-30 $\mu \mathrm{eq}^{-1}$ with no clear trend over time for the entire 17-year period (Fig. 3). Ambient $\mathrm{NO}_{3}$ deposition over this period also showed no trend over time, except for a slight decrease during the last few years (Tørseth et al., 1999). 

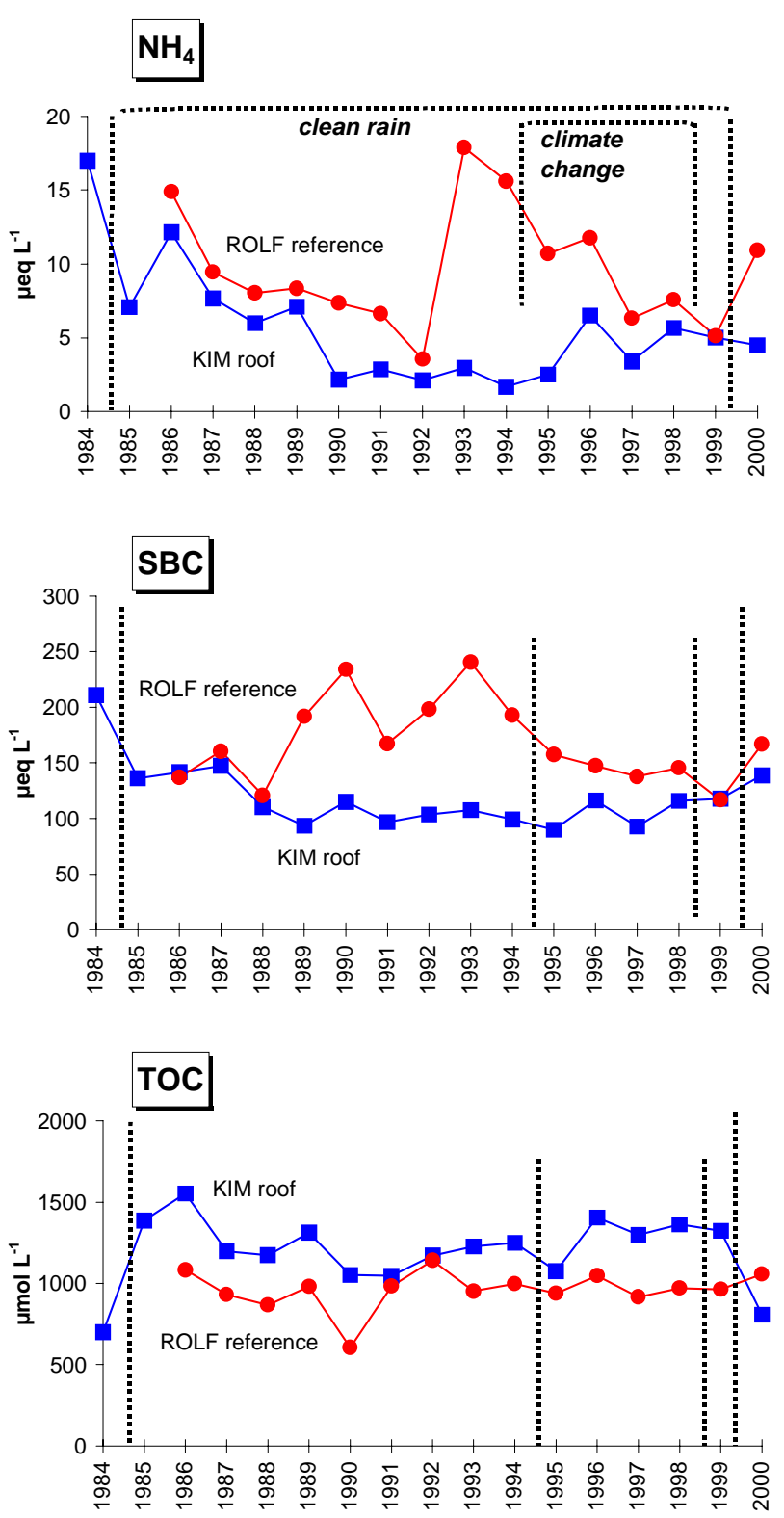

Fig. 5. Volume-weighted average concentrations of $\mathrm{NH}_{4}, \mathrm{SBC}$ and TOC in run-off at KIM (treatment, squares) and ROLF (reference, circles) catchments

Ammonium concentrations in run-off at KIM catchment also decreased in response to the clean rain treatment (Fig. 5 ) and by 1990 , concentrations were less than $5 \mu \mathrm{eq} \mathrm{l}^{-1}$. At ROLF catchment, $\mathrm{NH}_{4}$ concentration showed relatively large year-to-year variations but no significant trend over time. There was no significant trend in $\mathrm{NH}_{4}$ deposition during this period (Tørseth et al., 1999).

Under ambient conditions, before the clean rain treatment, KIM catchment retained about $50 \%$ of the incoming total $\mathrm{N}$ flux (Fig. 6). Following the decrease in $\mathrm{N}$ deposition in 1984, the catchment continued to leak a similar proportion. At
ROLF catchment, the net flux throughout the experimental period was very variable with a mean of $\mathrm{c} .60 \%$ retention. In 1995, with the start of the climate treatment at KIM catchment, both $\mathrm{NO}_{3}$ and $\mathrm{NH}_{4}$ concentrations in run-off increased relative to the previous years, despite the fact that deposition of $\mathrm{N}$ decreased due to the air-tight walls. The increase in response to climate treatment is reflected in the catchment N flux and from 1995-1999, KIM catchment switched from a small net sink to a small net source.

Concentrations of $\mathrm{Cl}$, the other major strong acid anion, varied very little in run-off at KIM catchment (Fig. 3). This is because the clean rain treatment first removed all ions (including sea-salts) by ion exchange, and then re-added sea-salts at a fixed concentration to the water sprinkled under the roof. At ROLF catchment, in contrast, concentrations of $\mathrm{Cl}$ in run-off varied from year-to-year by $\pm 50 \%$ in response to fluctuations in deposition fluxes. The years 1990, 1992 and 1993 were sea-salt-rich years and run-off had especially high concentrations of $\mathrm{Cl}$.

The decreased concentrations of the strong acid anions $\mathrm{SO}_{4}$ and $\mathrm{NO}_{3}$ in run-off at KIM catchment through to 1994 was compensated only slightly by a decrease in SBC (Fig. 5) and mainly by an increase in ANC (Fig. 7). Acid neutralising capacity showed a rapid increase over the first five years, from $c .-100 \mu \mathrm{eq} \mathrm{l}^{-1}$ in 1984 to $c .-20 \mu \mathrm{eq} \mathrm{l}^{-1}$ in 1989, followed by a slower increase to $c .-5 \mu$ eq $\mathrm{l}^{-1}$ in 1994 . Under the climate treatment, from 1994-1998, ANC further increased although only marginally. Following cessation of clean rain treatment in 1999, the ANC declined immediately to almost the same level as at ROLF.

At ROLF catchment, ANC also increased from c. $-90 \mu \mathrm{eq} \mathrm{l}^{-1}$ in the late $1980 \mathrm{~s}$ to $c$. $-40 \mu \mathrm{eq} \mathrm{l}^{-1}$ in 2000 . The trend in ANC at ROLF catchment, however, is much more noisy than that at KIM due to the large year-to-year variations primarily in sea-salt inputs and secondarily $\mathrm{SO}_{4}$ deposition. The increase in ANC at both catchments in response to clean rain treatment (KIM) and ambient deposition reduction (ROLF) was accompanied by decreased concentrations of $\mathrm{H}$ and inorganic species of aluminium (Al) (Fig. 7). At KIM catchment, concentrations

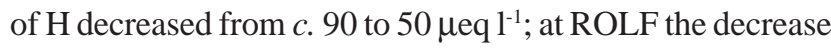
was to $c .60 \mu \mathrm{eq} \mathrm{l}^{-1}$. At KIM catchment, concentrations of Al decreased from $c .10$ to $2 \mu \mathrm{eq} \mathrm{l}^{-1}$, while at ROLF catchment the decrease was to $c .5 \mu$ eq $\mathrm{l}^{-1}$.

During the climate treatment, total organic carbon (TOC) concentration in run-off increased at KIM relative to ROLF catchment, indicating a release of TOC due to climate change (Fig. 5). This increased TOC at KIM catchment relative to ROLF catchment probably included some organic acids, yielding higher $\mathrm{H}$ (Fig. 7) and SBC (Fig. 5) concentrations and, hence, no change in ANC. 
KIM catchment (treatment)
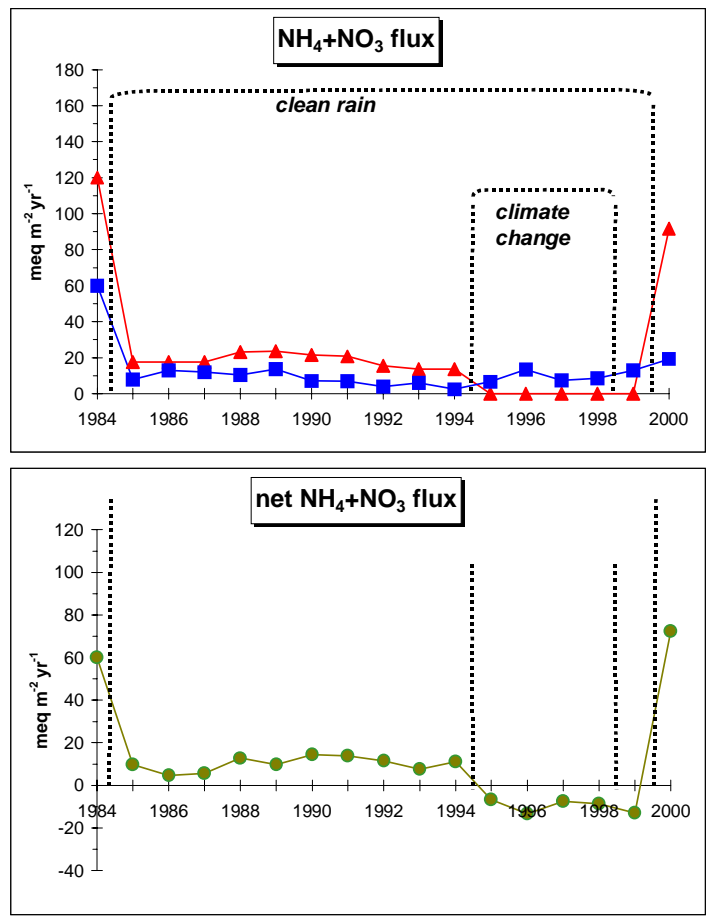

ROLF catchment (reference)
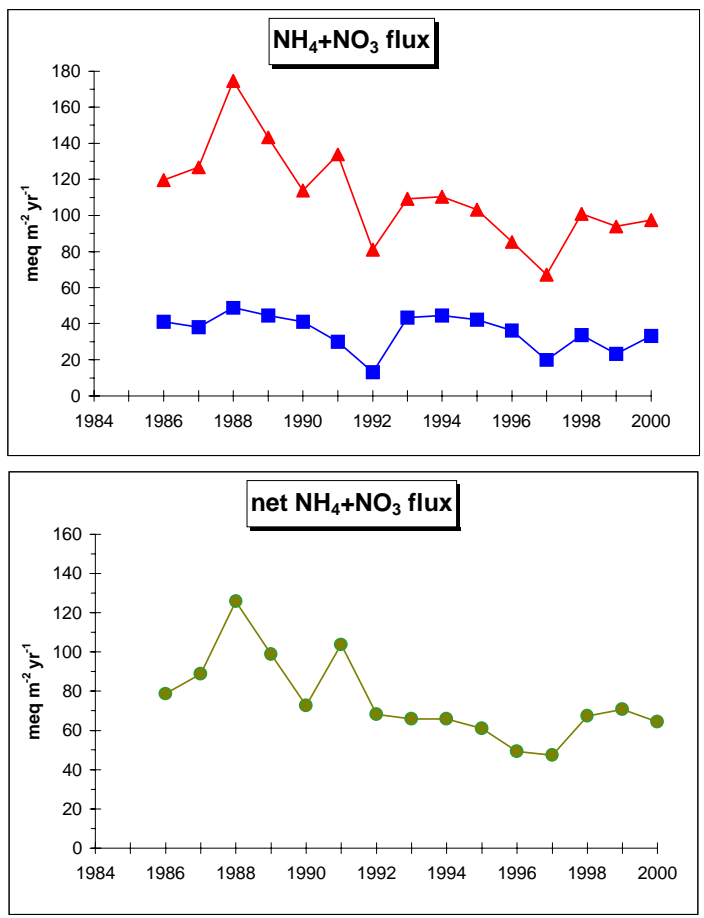

Fig. 6. Annual flux of inorganic nitrogen $\left(\mathrm{NH}_{4}+\mathrm{NO}_{3}\right)$ in deposition (in; triangles) and run-off (out; squares) and net flux (in-out) at KIM and ROLF catchments. Dotted lines denote start and end of the clean rain and climate change treatments at KIM catchment.

\section{Discussion}

In 1984 the roof at KIM catchment, Risdalsheia, was the first such whole-ecosystem experiment with reduced acid deposition. Similar roof experiments with clean rain were subsequently started in 1988 at Klosterhede, Denmark (Beier et al., 1998), in 1989 at Speuld and Ysselsteyn, the Netherlands (Boxman et al., 1995), in 1991 at Gårdsjön, Sweden (Hultberg et al., 1998) and in 1991 at Solling, Germany (Bredemeier et al., 1998). All these roof experiments entailed interception of the ambient acid deposition and sprinkling with an equivalent amount of clean, ion-exchanged water beneath the roof. The roofs at Risdalsheia and Gårdsjön covered entire catchments and output was measured in run-off, whereas the others were at forest stands and output was measured by soil leachate $(50$ $100 \mathrm{~cm}$ ) below the rooting zone. The roof at Risdalsheia was the only one above the tree canopy.

In all cases the concentrations of $\mathrm{SO}_{4}$ in soil solution or run-off decreased in response to the reduced $S$ inputs. Risdalsheia was one of the sites with a rapid response; the time required for volume-weighted annual mean concentrations of $\mathrm{SO}_{4}$ in run-off to decrease by $50 \%$ was about three years (Table 2). Klosterhede and Ysselsteyn also responded rapidly, Gårdsjön took somewhat longer (3-4 years), Speuld $>$ four years (the experiment was terminated) and Solling much longer (> 5 years). Beier et al. (1995) have compared the response at Risdalsheia, Gårdsjön and Klosterhede, and point out that the differences in response are probably due mostly to differences in soil, S storage and hydrology among the sites. The response at Klosterhede was further enhanced by the elimination of sea-salt $\mathrm{SO}_{4}$ as well. At Risdalsheia the combination of thin, young, welldrained soils with high annual precipitation leads to rapid flushing of old readily mobilised S from the soil. Solling has old, deeply-weathered soils, high in sequioxides that have large stores of absorbed $\mathrm{SO}_{4}$ that are released to soil leachate (Alewell et al., 1997).

At all the roof experiments the response in $\mathrm{NO}_{3}$ leaching was large and very rapid. Nitrate concentrations in run-off or soil leachate decreased by more than $50 \%$ for the first year of clean rain treatment, except at Speuld, a site receiving extremely high inputs of $\mathrm{NH}_{4}$. Here the response was slower, but then for only three years. Together these experiments show that the increased leaching of inorganic $\mathrm{N}$ below the rooting zone is rapidly reduced when $\mathrm{N}$ deposition is reduced, a direct demonstration of reversibility of this symptom of $\mathrm{N}$ saturation. 

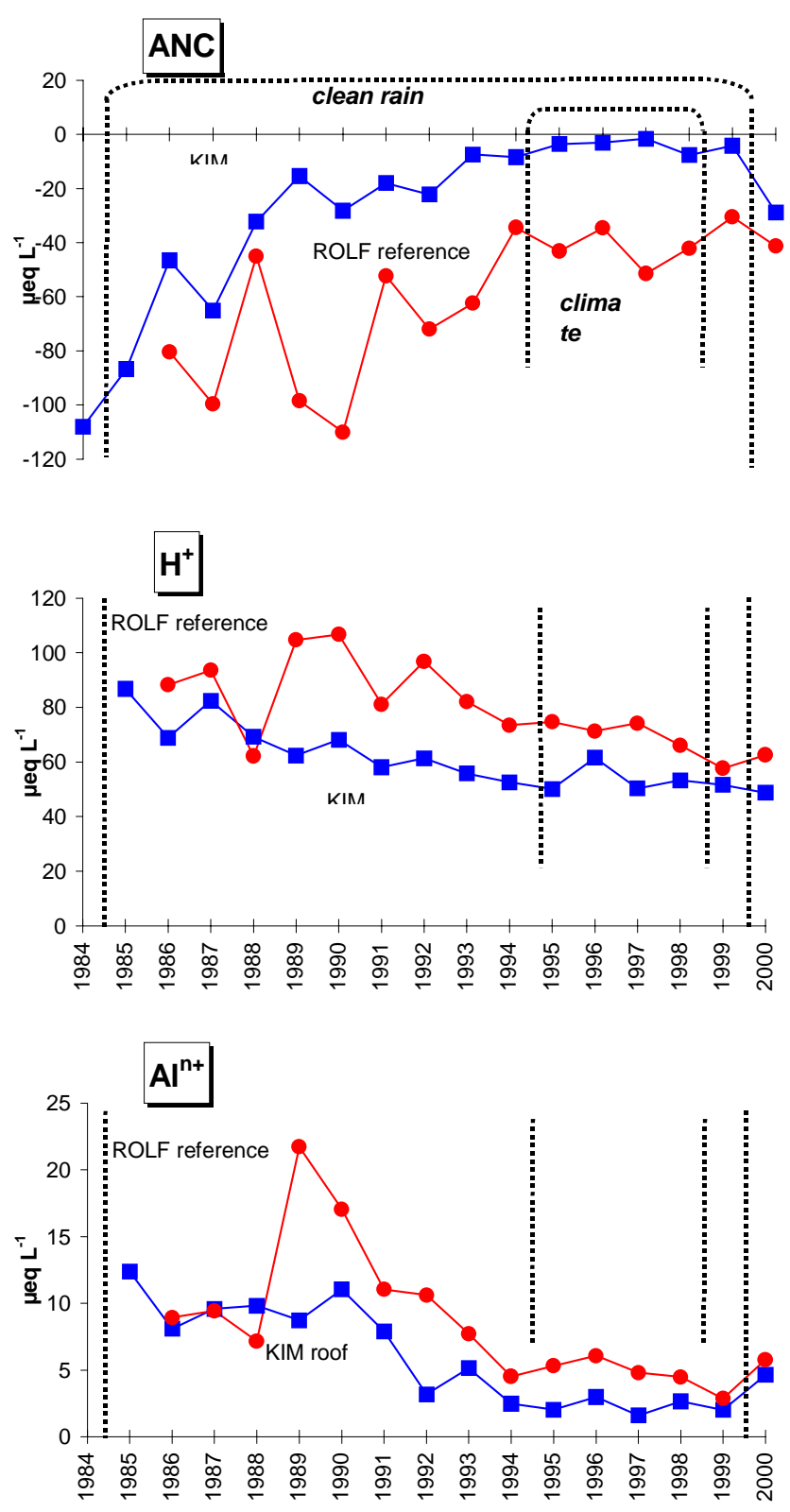

Fig. 7. Volume-weighted average concentrations of $A N C, H$, inorganic $A l, S B C$ and TOC in run-off at KIM (treatment, squares) and ROLF (reference, circles) catchments
The response in acid anions and associated response in base cations, ANC, $\mathrm{pH}$ and inorganic $\mathrm{Al}$ induced experimentally at Risdalsheia beginning in 1984, have subsequently been observed (albeit not to such a large degree) in the 1990s in lakes, streams and rivers over all of southern Norway (Skjelkvåle and Tørseth, 2001; Skjelkvåle et al., 2001a). The clean rain treatment at KIM catchment entailed $>80 \%$ reduction in both $\mathrm{S}$ and $\mathrm{N}$ deposition from the start of treatment in spring 1984, whereas southern Norway as a whole has had about 50\% reduction in S deposition since 1990 and 20\% reduction in $\mathrm{N}$ deposition since 1995. There appears, therefore, to be little doubt that the major trends measured at Risdalsheia can, to a large extent, be extrapolated to all of southernmost Norway.

The trends in run-off chemistry at KIM catchment were much smoother and monotonic relative to those at ROLF catchment. ROLF has a noisy signal primarily because of year-to-year variations in deposition of sea-salts and strong acids. The years 1990, 1992 and 1993 were particularly rich in sea-salts at ROLF catchment, as shown by the high volume-weighted concentrations of $\mathrm{Cl}$ in run-off (Fig. 3). The years 1987 and 1989 had high concentrations of $\mathrm{SO}_{4}$ in run-off, with unusually low concentrations for the intervening year 1988 (Fig. 3). As a result of these variations in $\mathrm{Cl}$ and $\mathrm{SO}_{4}$, the ANC in run-off at ROLF varied widely during the period 1987 to 1993 (Fig. 7). In particular 1989 and 1990 were years with very acid, Al-rich run-off at ROLF catchment, due to the combination of high inputs of both sea-salts and $\mathrm{SO}_{4}$ (Fig. 7). At KIM catchment, on the other hand, inputs of sea-salts were held constant during the entire treatment period 1985-1999. The comparison of the longterm records in run-off chemistry at ROLF catchment with those at KIM catchment illustrates, therefore, the confounding effect of sea-salt inputs on ANC, $\mathrm{H}$ and $\mathrm{Al}$ trends. The noise induced by sea-salt inputs is of the same magnitude as the signal due to decreasing inputs of S. During the period 1987-1999, ANC in run-off at ROLF catchment

Table 2. Length of time (years) required to achieve a 50\% decrease in $\mathrm{SO}_{4}$ and $\mathrm{NO}_{3}$ concentrations in soil solution (50-100 $\mathrm{cm}$ depth) or run-off at acid deposition exclusion (roof) experiments in Europe (in order of increasing response time for $\mathrm{SO}_{4}$ ). For $\mathrm{NO}_{3}$ there are no estimates for Klosterhede and Gårdsjön because no $\mathrm{NO}_{3}$ is present in the ambient situation

\begin{tabular}{llll}
\hline Site & $\mathrm{SO}_{4}$ & $\mathrm{NO}_{3}$ & Reference \\
\hline Klosterhede, Denmark & 1 & - & Beier et al., 1998 \\
Risdalsheia, Norway & 2 & $<1$ & Wright et al., 1988 \\
Ysselsteyn, The Netherlands & 2 & $<1$ & Boxman et al., 1995 \\
Gårdsjön, Sweden & 5 & - & Moldan, 1999 \\
Speuld, The Netherlands & $>4$ & 3 & Boxman et al., 1995 \\
Solling, Germany & $>5$ & $<1$ & Bredemeier et al., 1998 \\
\hline
\end{tabular}


increased by about $60 \mu$ eq $\mathrm{l}^{-1}$, but year-to-year variations were as large as $60 \mu$ eq $\mathrm{l}^{-1}$. Because of this high noise-tosignal ratio, detection of statistically significant trends in ANC in surface waters requires relatively large changes in $\mathrm{S}$ deposition and many years of data.

Variation in climate is another potential confounding factor. Analyses of trends in water chemistry at sites in the UK Acid Waters Monitoring network show that 1996 was unusual with high concentrations of $\mathrm{NO}_{3}$, apparently due to a cold winter and increased mineralisation and nitrification in the soil (Monteith et al., 2000; Evans and Monteith, 2001). A similar explanation has been offered for the anomalously high concentrations of $\mathrm{NO}_{3}$ in run-off in the spring following the cold winter of 1989-1990 in the northeastern United States (Mitchell et al., 1996).

The CLIMEX experiment at Risdalsheia represents four anomalously warm years superimposed upon the 15 year clean rain treatment. At Risdalsheia it is the warm years that gave high concentrations of $\mathrm{NO}_{3}$ (and to a lesser extent $\mathrm{NH}_{4}$ ) in run-off (Wright, 1998). Measurement of $\mathrm{N}$ mineralisation in soils at Risdalsheia showed a statistically significant increase of $50 \%$ at KIM catchment relative to the reference during the second year of treatment (Verburg et al., 1999b; Verburg and van Breemen, 2000).

The $\mathrm{N}$ input-output budgets show that with the onset of warming and increased $\mathrm{CO}_{2}$ treatment, the ecosystem switched from a net sink to a net source of inorganic $\mathrm{N}$ (Fig. 7). During the entire 11 year period prior to the climate change treatment (1984-1994) the ecosystem was a net sink for N, a situation typical for most boreal forests (Tamm, 1991). The ecosystem lost $\mathrm{N}$ during all four years of climate change treatment, probably due to the increased decomposition of soil organic matter and release of $\mathrm{N}$ to soil solution. After only four years of warming it is difficult to judge whether the increased $\mathrm{N}$ release is merely a transient phenomenon.

The leaching of $\mathrm{N}$ continued also during the year posttreatment (June 1998 - May 1999), despite the fact that the temperature (and $\mathrm{CO}_{2}$ ) levels beneath the roof were no longer different from ambient levels (Figs. 3 and 6). Just as there was a delay in the increase in rate of mineralisation following the start of the warming, there appears to be a delay in the decrease in rate following return to lower temperatures. This suggests that the microbial community cannot respond immediately to the changed temperature and needs time to adapt to the new conditions.

The climate change treatment at KIM catchment also caused clear alteration of the regular seasonal pattern of TOC concentrations in run-off (not shown). Prior to treatment at KIM catchment, and for all years at the reference catchment ROLF, the concentrations of TOC show a marked pattern of high levels in mid-summer and low levels in midwinter. This pattern largely disappears during the four years of climate change treatment at KIM, but then reappears in the post-treatment "recovery" year 1998-1999.

The phenomenon appears to be related to winter temperatures in that during warm winters the ecosystem continues to release higher levels of TOC to run-off. During the four years of the CLIMEX treatment, the mean winter temperature in the KIM catchment was nearly always above $0^{\circ} \mathrm{C}$, while the years prior to and following treatment commonly had winter temperatures below freezing. The fact that the TOC pattern resumed during the post-treatment year, but the release of $\mathrm{NO}_{3}$ in run-off remained high, indicates that the processes responsible for release of TOC to run-off are different from those governing the release of $\mathrm{NO}_{3}$ to run-off.

During the final year (August 1999-May 2000) the roof panels were removed and KIM catchment was exposed to ambient acid deposition after 16 years of clean rain treatment. Run-off chemistry re-acidified and after only one year resembled that at ROLF catchment. Concentrations of $\mathrm{SO}_{4}$ increased sharply (Fig. 3), ANC decreased (Fig. 7), and $\mathrm{Al}$ increased (Fig. 7). This final year thus provided a confirmation of the 16 year clean rain experiment.

\section{Acknowledgements}

Financial support for the RAIN project came from the Norwegian Ministry of Environment, the Research Council of Norway (and its predecessors), Environment Canada, the Ontario Ministry of Environment, the Swedish Environmental Protection Board, the Central Electricity Generating Board (UK), National Power (UK), the Surface Water Acidification Programme (SWAP) and internal research funds from NIVA and NILU. Financial support for CLIMEX came from the Commission of European Communities (EV5V-CT91-0047 and EV5V-CT95-0185), the Dutch Global Change Programme, the Research Council of Norway, the Norwegian Ministry of Environment, the Natural Environment Research Council (UK), Hydrogas Norge A/S and the Norwegian Institute for Water Research. The synthesis and analysis of results reported here was carried out as part of the RECOVER:2010 project (the Commission of European Communities EVK1-CT-199900018). We thank Ann Kristin Buan, Rolf Høgberget, Jarle Håvardstun, Mette Lie and Tore Sørvåg for assistance.

\section{References}

Alewell, C., Bredemeier, M., Matzner, E. and Blanck, K., 1997. Soil solution response to experimentally reduced acid deposition in a forest ecosystem. J. Environ. Qual., 26, 658-665. 
Beier, C., Hultberg, H., Moldan, F. and Wright, R.F., 1995. MAGIC applied to roof experiments (Risdalsheia, N; Gårdsjön, S; Klosterhede, DK) to evaluate the rate of reversibility of acidification following experimentally reduced acid deposition. Water Air Soil Pollut., 85, 1745-1751.

Beier, C., Blanck, K., Bredemeier, M., Lamersdorf, N., Rasmussen, L. and Xu, Y.J., 1998. Field-scale "clean rain" treatments to two Norway spruce stands within the EXMAN project - effects on soil solution chemistry, foliar nutrition and tree growth. Forest Ecol. Manage., 101, 111-123.

Boxman, A.W., van Dam, D., van Dijk, H.F.G., Hogervorst, R.F. and Koopmans, C.J., 1995. Ecosystem responses to reduced nitrogen and sulphur inputs into two coniferous forest stands in the Netherlands. Forest Ecol. Manage., 71, 7-29.

Bredemeier, M., Blanck, K., Dohrenbusch, A., Lamersdorf, N., Meyer, A.C., Murach, D., Parth, A. and Xu, Y.J., 1998. The Solling roof project - site characteristics, experiments and results. Forest Ecol. Manage., 101, 281-294.

Dise, N.B. and Jenkins, A., 1995. The CLIMEX project: Whole catchment manipulations of $\mathrm{CO}_{2}$ and temperature. Climate Change Research Report 3/1995, Norwegian Institute for Water Research, Oslo, Norway, $130 \mathrm{pp}$.

Evans, C.D., Cullen, J.M., Alewell, C., Marchetto, A., Moldan, F., Kopácek, J., Prechtel, A., Rogora, M., Veselý, J. and Wright, R.F., 2001. Recovery from acidification in European surface waters. Hydrol. Earth Syst. Sci., 5, 283-297.

Evans, C.D. and Monteith, D.T., 2001. Trends in surface water chemistry at AWMN sites 1988-2000. Hydrol. Earth Syst. Sci., 5, 351-366.

Hultberg, H., Moldan, F., Andersson, B.I. and Skeffington, R.A., 1998. Recovery from acidification in the forested covered catchment experiment at Gårdsjön: effects on biogeochemical output fluxes and concentrations. In: Experimental Reversal of Acid Rain Effects. The Gårdsjön Roof Project, H. Hultberg and R. Skeffington (Eds.), 157-184. Wiley, Chichester, UK.

Lükewille, A. and Wright, R.F., 1997. Experimentally increased soil temperature causes release of nitrogen at a boreal forest catchment in southern Norway. Glob. Change Biol., 3, 13-21.

Mitchell, M.J., Driscoll, C.T., Kahl, J.S., Likens, G.E., Murdoch, P.S. and Pardo, L.H., 1996. Climatic control of nitrate loss from forested watersheds in the northeast United States. Environ. Sci. Technol., 30, 2609-2612.

Moldan, F., 1999. Reversal of Soil and Water Acidification in S.W. Sweden, Simulating the Recovery Process. Swedish University of Agricultural Sciences, Umeå, Sweden, Doctoral thesis.

Monteith, D.T., Evans, C.D. and Reynolds, B., 2000. Are temporal variations in the nitrate content of UK upland freshwaters linked to the North Atlantic Oscillation? Hydrol. Process., 14, 17451749.

Skjelkvåle, B.L., Andersen, T., Fjeld, E., Mannio, J. and Wilander, A., 2001a. Recovery from acidification of lakes in Finland, Norway and Sweden 1990-1999. Hydrol. Earth Syst. Sci., 5, 327-337.
Skjelkvåle, B.L. and Tørseth, K., 2001. Decrease in acid deposition - recovery in Norwegian waters. Water Air Soil Pollut., (in press).

Skjelkvåle, B.L., Stoddard, J.L. and Andersen, T., 2001b. Trends in surface waters acidification in Europe and North America (1989-1998). Water Air Soil Pollut., (in press).

Stoddard, J.L., Jeffries, D.S., Lükewille, A., Clair, T.A., Dillon, P.J., Driscoll, C.T., Forsius, M., Johannessen, M., Kahl, J.S., Kellogg, J.H., Kemp, A., Mannio, J., Monteith, D.T., Murdoch, P.S., Patrick, S., Rebsdorf, A., Skjelkvåle, B.L., Stainton, M.P., Traaen, T.S., van Dam, H., Webster, K.E., Wieting, J. and Wilander, A., 1999. Regional trends in aquatic recovery from acidification in North America and Europe 1980-95. Nature, 401, 575-578.

Tamm, C.O., 1991. Nitrogen in Terrestrial Ecosystems. Ecological Studies 81. Springer, Berlin, 115 pp.

Tørseth, K., Berg, T., Hanssen, J.E. and Manø, S., 1999. Overvåking av langtransportert forurenset luft og nedbør. Atmosfærisk tilførsel, 1998. Statlig program for forurensningsovervåking Rapport 768/99, Statens forurensningstilsyn, Oslo, Norway.

van Breemen, N., Jenkins, A., Wright, R.F., Arp, W.J., Beerling, D.J., Berendse, F., Beier, C., Collins, R., van Dam, D., Rasmussen, L., Verburg, P.S.J. and Wills, M.A. 1998. Impacts of elevated carbon dioxide and temperature on a boreal forest ecosystem (CLIMEX project). Ecosystems, 1, 345-351.

Verburg, P.S.J. and van Breemen, N., 2000. Experimental manipulation of a forested catchment: litter decomposition and N mineralization. Forest Ecol. Manage., 129, 31-39.

Verburg, P.S.J., van Loon, W.K.P. and Lükewille, A., 1999a. The CLIMEX soil heating experiment: soil response after 2 years of treatment. Biol. Fert. Soils, 28, 271-276.

Verburg, P.S.J., van Dam, H., Hefting, M.M. and Tietema, A., 1999b. Effects of elevated temperature on microbial transformations of $\mathrm{C}$ and $\mathrm{N}$ in a boreal forest floor. Plant Soil, 208, 189-197.

Wright, R.F., 1987. Rain Project: Results after 2 years of treatment. In: Reversibility of Acidification, H. Barth (Ed.), 14-49. Elsevier Applied Science, London.

Wright, R.F., 1998. Effect of increased $\mathrm{CO}_{2}$ and temperature on run-off chemistry at a forested catchment in southern Norway (CLIMEX project). Ecosystems, 1, 216-225.

Wright, R.F., Lotse, E. and Semb, A., 1993. RAIN project: results after 8 years of experimentally reduced acid deposition. Can. J. Fisheries Aquat. Sci., 50, 258-268.

Wright, R.F., Gjessing, E., Christophersen, N., Lotse, E., Seip, H.M., Semb, A., Sletaune, B., Storhaug, R. and Wedum, K., 1986. Project RAIN: changing acid deposition to whole catchments. The first year of treatment. Water Air Soil Pollut., 30, 47-63.

Wright, R.F., Lotse, E. and Semb, A., 1988. Reversibility of acidification shown by whole-catchment experiments. Nature, 334, 670-675. 